\title{
RESEARCH
}

\section{Analysis Tolerance of Monosodium Glutamate (MSG) In instant noodles With Uv-Vis Spectrophotometry}

\author{
Firstca Aulia rachma ${ }^{1, *}$ and Tunik Saptawati ${ }^{1}$
}

\begin{abstract}
Background: MSG has become one of the most widely used food flavorings in the world, the FDA (Food and Drug Administration) reported an average per capita intake of MSG in the United States of $550 \mathrm{mg} /$ day in 1973. The use of MSG as a food additive has been regulated by its use. WHO. This rule stipulates that daily consumption of MSG per person should not exceed the safe threshold of $120 \mathrm{mg} / \mathrm{kg} /$ day. MSG is proven to be a risk factor for obesity. The increase in body weight in mice occurred after MSG was given as much as 15$30 \mathrm{mg} / \mathrm{kg}$ or the equivalent of $1-2 \mathrm{~g} /$ person. Based on the description above, it is known that there is a significant influence of MSG in the health sector if consumed in excess. Therefore, researchers are interested in conducting further research related to MSG levels in instant noodle samples in the Semarang city area.

Aim: The purpose of this study was to test the MSG levels in instant noodles with a spectrophotometer Method: The tools used are a UV-Vis spectrophotometer (Shimadzu), NaCl and MSG salts. MSG used in instant noodles, $0.5 \%$ Ninhydrin Reagent.

Result: MSG levels from each of the 10 samples of instant noodles that are traded in Semarang City, the highest levels are found in sample $\mathrm{J}$ of $4.70 \%$ and the lowest MSG levels are in sample $\mathrm{G}$ of $2.90 \%$.

Conclusion: Instant noodles sold in the city of Semarang are positive for Monosodium glutamate (MSG) and The results of quantitative analysis, where the MSG levels contained in each sample of instant noodles in Semarang City show that it is still below the standard for adults.
\end{abstract}

Keywords: Monosodium glutamate, instan noodles, spectrophotometry

\section{BACKGROUD}

Currently, MSG has become one of the most commonly used food seasonings in the world ${ }^{1}$. The General Recognized as Safe (GRAS) Committee at the FDA (Food and Drug Administration) reports the average per capita intake of MSG in the United States is $550 \mathrm{mg} /$ day $^{2}$. The use of MSG as a food additive has been regulated by WHO. This rule stipulates that the daily consumption of MSG per person should not exceed the safe limit of $120 \mathrm{mg} / \mathrm{kg} /$ day $^{3}$.

Most people in Indonesia consume an average of $0.6 \mathrm{~g} /$ day of $\mathrm{MSG}^{4}$. This shows that the consumption of MSG in the world has increased dramatically. This increase is thought to be associated with an increased incidence of obesity. Instant noodles are a food ingredient practical and fast in processing. Besides it is a variety of flavors and complementary in instant noodle packaging has been widely circulating in market, so that it does not make it difficult for humans in consuming it. Various variants of noodles both fried and boiled noodles are produced with a wide selection of flavors to make a choice more and more consumers.

${ }^{*}$ Correspondence: firstca@stikestelogorejo.ac.id

1 Department of Pharmacy, STIKES Telogorejo Semarang, Indonesia

Full list of author information is available at the end of the article 
According to research conducted on experimental animals ${ }^{5,6,7}$ and humans ${ }^{8,9}$, MSG is shown to be risk factors for obesity. For decades MSG was still associated with causes of cancer,heart attack, obesity, asthma, and disease others, even affecting intelligence ${ }^{10}$. Many foods are consumed by society is not known the content of these foods. Moreover, the type of food contains MSG, often not mentioned levels in a packaged food. The increase in body weight of mice occurred after MSG administration of $15-30 \mathrm{mg} / \mathrm{kg}$ or equivalent to $1-2 \mathrm{~g} /$ person $^{11}$. Based on the description above, it is known that the influence of MSG is quite large in the health sector if consumed in excess. Therefore, the researcher is interested in conducting further research related to the analysis of MSG levels in instant noodles. The purpose of this research is to determine whether the instant noodles that are being traded are safe for consumption or not and to measure the levels of MSG in food by UV-Vis spectrophotometry.

\section{METHODS}

\section{Materials}

The tools used are a UV-Vis spectrophotometer (Shimadzu), Ion-free water, $\mathrm{NaCl}$ and MSG salts. MSG used in instant noodles. This study requires MSG $\pm 40 \mathrm{~g}$ to be used, $0.5 \%$ Ninhydrin Reagent

\section{Analysis of MSG using spectrophotometry}

Determination of the Maximum Wavelength of MSG, namely with the standard solution of MSG 50bpj added $4 \mathrm{ml}$ of $0.5 \%$ ninhydrin solution then heated into a water bath for several minutes until a blue color was formed. After cooling, the absorption was measured, the maximum absorption was obtained at a wavelength of $571.0 \mathrm{~nm}$. Preparation of standard curves using pipettes correctly 1, 2, 3, 4, 5, 6, 7, 8, 9, and $10 \mathrm{ml}$ of MSG standard solution (500 bpj) into a $50 \mathrm{ml}$ volumetric flask, added $4 \mathrm{ml}$ of ninhydrin $0,5 \%$ then diluted with aquadest to mark the line so that the respective concentrations are $10 \mathrm{ppm}, 20 \mathrm{ppm}, 30 \mathrm{ppm}, 40$ ppm, 50 ppm, 60 ppm, 70 ppm, 80 ppm, 90 ppm, and 100 ppm. Then it is heated into a water bath for a few minutes until it forms a blue color. After cooling, the absorption was measured at a wavelength of $571 \mathrm{~nm}$. In measuring MSG levels in the sample, the sample solution was piped $1 \mathrm{ml}$, put into a test tube, added $4 \mathrm{ml}$ of $0.5 \%$ ninhydrin solution then heated into a water bath for a few minutes until a blue color was formed. After being cooled, $1 \mathrm{ml}$ pipette was then put into a $250 \mathrm{ml}$ volumetric flask and added aquadest to mark the line and then homogenized, measured the absorption at a wavelength of $571 \mathrm{~nm}$.

Furthermore, the calculation of monosodium glutamate (MSG) levels is calculated by entering the sample absorption data into the linear regression equation of the MSG standard tortoise. The data processing is based on the results of the measurement of the absorption of the bakud solution with the maximum wavelength tabulated in the form of a graph between absorption and concentration, where the absorption values are on the $\mathrm{X}$ axis, then a line is drawn between the points. To obtain a straight-line equation.

\section{RESULTS}

\section{Determination of the maximum MSG wavelength}

The standard solution of MSG 50bpj was added with $4 \mathrm{ml}$ of $0.5 \%$ ninhydrin solution. Then it was heated into a water bath for several minutes until it formed a blue color. After cooling, the absorption was measured, and the maximum absorption was obtained at a wavelength of $571.0 \mathrm{~nm}$.

\section{Calibration curves}

The calibration curve is an empirical calculation that relates the response of the tool to the concentration of a particular analyte. The resulting absorbance will have a linear relationship with the concentration of the analyte measured according to Lambert's Law. 
Table 1. Data on the measurement results of the absorption of MSG standard solutions with various concentrations using the Visible Light spectrophotometer at a wavelength of $571 \mathrm{~nm}$

\begin{tabular}{ccc}
\hline Standart & Consentration & Absoption \\
\hline 1 & 0,00 & 0,0313 \\
2 & 10 & 0,0549 \\
3 & 30 & 0,0941 \\
4 & 50 & 0,1287 \\
5 & 70 & 0,1674 \\
6 & 100 & 0,1921 \\
\hline
\end{tabular}

Regression line equation: $\mathrm{y}=\mathrm{a}+\mathrm{bx} \mathrm{y}=0.03638+0.00163 \mathrm{x} \mathrm{r}=0.997$

\section{Determination of MSG Levels in Instant Noodle Samples}

Data on the results of determination of MSG levels on instant noodle samples by visible light spectrophotometer at a wavelength of $571.0 \mathrm{~nm}$.

Tabel 2. MSG levels on intsn noodle

\begin{tabular}{cccc}
\hline No & $\begin{array}{l}\text { Code } \\
\text { Sampel }\end{array}$ & $\begin{array}{l}\text { Kadar } \\
(\mathbf{m g} / \mathbf{k g})\end{array}$ & \% MSG (\%b/b) \\
\hline 1 & A & 28859,14 & 2,99 \\
2 & B & 37549,90 & 3,75 \\
3 & C & 32484,83 & 3,25 \\
4 & D & 35096,17 & 3,51 \\
5 & E & 41182,80 & 4,12 \\
6 & F & 38984,66 & 3,90 \\
7. & G & 29718,45 & 2,90 \\
8. & H & 43126,90 & 4,31 \\
9. & I & 37377,73 & 3,74 \\
10 & J & 45994,16 & 4,70 \\
\hline
\end{tabular}

Table 2 shows the results of the examination of MSG levels from each of the 10 samples of instant noodles that are traded in Semarang City, the highest levels are found in sample $\mathrm{J}$ of $4.70 \%$ and the lowest MSG levels are in sample $G$ of $2.90 \%$. in each sample is still below the levels stipulated by the FDA and WHO, namely $120 \mathrm{mg} / \mathrm{kgBB} /$ day as the standard used for body weight of $50 \mathrm{~kg}$ for Indonesia and other developing countries.

\section{DISCUSSION}

In the ninhydrin test, a solution of ten samples of instant noodles was added each $0.5 \%$ ninhydrin reagent then heated into a water bath for a few minutes so that the ninhydrin could react with free $\alpha$ - amino acids found in monosodium glutamate which was indicated by a change in color from clear to blue and the results obtained from the ten samples are positive for Monosodium Glutamate (MSG). In the biuret test, ten sample solutions were alkalized with $10 \% \mathrm{NaOH}$ solution and added with $0.1 \% \mathrm{CuSO} 4$ reagent reacting with Monosodium glutamate (MSG) in an alkaline state marked by a change in color from clear to blue and the results obtained were all positive samples containing Monosodium glutamate (MSG). Determination of levels in a positive sample containing MSG, the sample is then analyzed using a Visible Light Spectrophotometer. The results showed that the absorbance value and wavelength of the standard solution of monosodium glutamate at a concentration of $50 \mathrm{ppm}$, namely a wavelength of $571.0 \mathrm{~nm}$ with an absorbance of 0.091 .

Based on the results obtained, it can be seen that the total MSG content of each of the 10 samples of instant noodles sold and traded in Semarang City is the highest in sample $\mathrm{J}$ of $4.70 \%$ and the lowest MSG 
content is in sample $\mathrm{G}$ of $2.90 \%$. The results of MSG levels in each sample of instant noodles with FDA and WHO provisions, namely $120 \mathrm{mg} / \mathrm{kgBB} /$ day or $6 \mathrm{~g} / 50 \mathrm{kgBB} /$ day as the standard used $50 \mathrm{~kg}$ body weight for the State of Indonesia showed a significant difference ( $<<0,05)$, however, the average MSG level obtained from each sample is still deemed to meet the standards under the dosage provisions by WHO / FDA. The total MSG level in instant noodles still meets the requirements for consumption by adults with a standard weight of $50 \mathrm{~kg}$ based on the dosage used by WHO / FDA, namely $120 \mathrm{mg} / \mathrm{kg}$ BW / day or $6 \mathrm{~g} /$ $50 \mathrm{kgBB} /$ day. In America, 5\% of the population is sick because of consuming MSG, and it is estimated that this number will continue to increase. Even though the research results obtained on instant noodles are safe for consumption, it is still necessary to pay attention to the dosage of use, especially for consumers who are sensitive to MSG, they must be more careful in choose foods that contain MSG and if necessary do not consume MSG considering that $0.5 \mathrm{~g}$ to $2.5 \mathrm{~g}$ of MSG can provide reactions such as asthma attacks, headaches, hypertension, brain tumors, strokes, anemia, and other diseases.

\section{CONCLUSION}

Based on the results of the research that has been done, it can be concluded as follows that Instant noodles sold in the city of Semarang are positive for Monosodium glutamate (MSG). The results of quantitative analysis, where the MSG levels contained in each sample of instant noodles in Semarang City show that it is still below the standard for adults with a standard weight of $50 \mathrm{~kg}$ based on the dosage used by WHO / FDA, namely $120 \mathrm{mg} / \mathrm{kg} \mathrm{BW}$, where the highest level is sample $\mathrm{J}$ of $4.70 \%$ and the lowest MSG levels are in sample $\mathrm{G}$ of $2.90 \%$. The use of MSG, which is a food additive, has been regulated by WHO. This rule stipulates that daily consumption of MSG per person should not exceed the safe threshold of $120 \mathrm{mg} / \mathrm{kg} /$ day

\section{ACKNOWLEDGEMENT}

Alhamdulillahi rabil 'alamin, the researcher expressed his gratitude to Allah subhanahu wa ta'ala for his blessings, love, opportunity, health, and grace for completing this research. This research is entitled "Analysis Of Tolerance Of Monosodium Glutamate (MSG) In instant noodles With Uv-Vis Spectrophotometry". In the preparation of this research, many parties have provided motivation, advice and support for researchers. In this valuable opportunity, express his gratitude and appreciation to all parties. First, the researchers' deepest appreciation goes to beloved parents, especially mothers and fathers for their endless love, prayer and support, and prayer. Second, to the S-1 Pharmacy Study Program of STIKES Telogorejo, Semarang for their support and support.

\section{CONFLICT OF INTEREST}

Researchers do not experience conflicts of interest with all research teams or with the authors referred to for the preparation of the publication manuscript.

\section{AUTHORS' CONTRIBUTION}

AP was in charge of collecting data on antioxidant activity. YF is in charge of making the peel off gel mask formula. ND is in charge of drafting proposals, final reports and research publications.

\section{FUNDING}

None 


\section{AUTHOR DETAILS}

${ }^{1}$ Department of pharmacy, STIKES Telogorejo Semarang, Indonesia

\section{REFERENCES}

1. Husarova, V. and Ostatnikova, D., 2013. Monosodium glutamate toxic effects and their implications for human intake: a review. Jmed Research, 2013(2013), pp.1-12.

2. He, K., Du, S., Xun, P., Sharma, S., Wang, H., Zhai, F. and Popkin, B., 2011. Consumption of monosodium glutamate in relation to incidence of overweight in Chinese adults: China Health and Nutrition Survey (CHNS). The American journal of clinical nutrition, 93(6), pp.1328-1336.

3. Anonim. (2011). FDA Drug Safety Communication : Monosodium Glutamate (MSG). Dipetik Januari 10, 2018, dari U.S. Department of Health and Human Services: https://www.fda.gov/food/food-additives-petitions/questions-and-answers-monosodiumglutamate-msg

4. Prawirohardjono W, Dwiprahasto I, Astuti I, Hadiwandowo S, Kristin E, Muhammad M, et al., (2000) The administration to indonesians of monosodium l-glutamate in indonesian foods: an assessment of adverse reactions in a randomized double-blind, placebo-controlled study. $J$ Nutr

5. Dolnikoff, M., Hidalgo, A. M., Machado, U. F., Lima, F. B. \& Herrera, E. 2001, Decreased lipolysis and enhanced glycerol and glucose utilization by adipose tissue prior to development of obesity in monosodium glutamate (MSG) treated-ratse, Int J Obes Relat Metab Disord, vol. 25, no. 3, pp. 426-433

6. Souza, C. T., Nunes, W. M., Gobatto, C. A. \& Mello, M. A. (2003). Insulin secretion in monosodium glutamate (MSG) obese rats submitted to aerobic exercise training, Physiol Chem Phys Med NMR, vol. 35, no. 1, pp. 43-53.

7. Matysková, R., Maletínská, L., Maixnerová, J., Pirnik, Z., Kiss, A. \& Zelezna, B. (2008), Comparison of the obesity phenotypes related to monosodium glutamate effect on arcuate nucleus and/or the high fat diet feeding in C57BL/6 and NMRI mice, Physiol Res, vol. 57, pp. 727-734.

8. He, K., Zhao, L., Daviglus, M. L., Dyer, A. R., Horn, L. V. \& Garside, D. (2008) .Association of monosodium glutamate intake with overweight in Chinese adults: the INTERMAP Study. Obesity (Silver Spring), vol. 16, pp. 1875-1880.

9. Yeomans, M. R., Gould, N. J., Mobini, S. \& Prescott, J. (2008) .Acquired flavor acceptance and intake facilitated by monosodium glutamate in humans. Physiol Behav, vol. 93, pp. 958966.

10. Wibowo, Surya dan Suryani Dyah. (2013). Pengaruh Promosi Kesehatan Metode Audio Visual dan Metode Buku Saku Terhadap Peningkatan Pengetahuan Penggunaan Monosodium Glutamat (MSG) Pada Ibu Rumah Tangga. KESMAS. 7(2).pp. 55

11. Falalieieva TM, Kukhars'ky̌̌ VM and Berehova TV., (2010). Effect of long-term monosodium glutamate administration on structure and functional state of the stomach and body weight in rats. Fiziol Zh. 56: 102-110. 